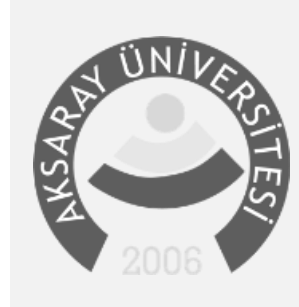

AKSARAY ÜNIVERSITESI

İKTİSADİ VE İDARİ BİLIMLER FAKÜLTESİ DERGİSI

JOURNAL OF AKSARAY UNIVERSITY FACULTY OF ECONOMICS

AND ADMINISTRATIVE SCIENCES

dergipark.gov.tr/aksarayiibc

Araștırma Makalesi • Research Article

\title{
COVID-19 Pandemide Uzaktan Çalışan Z Kuşağı Kadınların Kariyer Yolu Tercihleri ve İşten Ayrılma Niyeti İlişkisi
}

\author{
The Relationship Between Career Path Preferences and Intention to Quit Job of Generation Z \\ Women Remote Working in COVID-19 Pandemic
}

\author{
Aslı Çillioğlu Karademir ${ }^{1}$ ve Burcu Kirt ${ }^{2}$ \\ ${ }^{1}$ Dr. Öğr. Üyesi, Bartın Üniversitesi, İktisadi ve İdari Bilimler Fakültesi, İsletme Bölümü, akarademir@bartin.edu.tr, Orcid Id: 0000-0001- \\ 5208-7345 \\ ${ }^{2}$ Yüksek Lisans Öğrencisi, Bartın Üniversitesi, Lisansüstü Eğitim Enstitüsü, burcukirt@ gmail.com, Orcid Id:0000-0002-2207-8939
}

M A K A L E B İ L G İ S I

\section{Anahtar Kelimeler}

Kariyer Yolu Tercihleri,

Işsten Ayrılma Niyeti,

Z Kuşă̆l,

Kadın Çalışanlar,

COVID-19

\section{Makale Geçmiși:}

Geliș Tarihi: 22 Şubat 2021

Kabul Tarihi: 2 Nisan 2021

A R T I C LE IN F O

\section{Keywords}

Career Path Preferences,

Intention to Quit Job,

Generation Z,

Women Employees,

COVID-19

\section{Ö Z E T}

Kariyer yolu tercihi ve işten ayrılma ya da işte kalma kararı kariyer sürecindeki en kritik adımlardandır. Bireysel farklılıklar ve istekler ile çevre koşulları kariyer yolu tercihlerine yansımaktadır. Z kuşağının ve kadınların sahip olduğu farklılıkların çalışma hayatında kariyer gelişimini değiştirmesi beklenmektedir. Ayrıca COVID-19 pandemi sürecinde çalışma hayatının yaşamakta olduğu dönüşüm, çalışanların kariyer yolu tercihlerini etkilemektedir. Bu doğrultuda araştırmanın amacı, Türkiye'de uzaktan çalışan Z kuşağı kadınların kariyer yolu tercihleri ile işten ayrılma niyetleri arasındaki ilişkiyi incelemektir. Araştırmanın örneklemini uzaktan çalışan $146 \mathrm{Z}$ kuşağı kadın oluşturmaktadır. Veri toplama aracı olarak anket kullanılmıştır. Veri analizinde merkezi eğilim ve dağılım ölçümleri, korelasyon, ANOVA ve t-testi yapılmıştır. Anket yanıtlarının madde, boyut ve değişkenlere göre ortalamaları yorumlanmıştır. İşten ayrılma niyeti ile kariyer yolu tercihleri arasında pozitif yönde zayıf ilişki olduğu belirlenmiştir. Çalışanların mezun oldukları yani eğitim aldıkları mesleki alanda çalışmak istedikleri, bununla beraber yönetici olarak yeni beceriler kazanmaya ve projelerde yeni yeterlilikler edinmeye açık oldukları görülmüştür.

\begin{abstract}
A B S T R A C T
Choosing a career path and the decision to quit or stay at work are the most critical steps in the career process. Individual differences, desires and environmental conditions are reflected in career path preferences. The differences between the generation $\mathrm{Z}$ and women are expected to change career development in working life. In addition, the transformation of working life during the COVID-19 pandemic process affects the career path preferences of employees. In this respect, the purpose of the study is to examine the relationship between career path preferences of generation $\mathrm{Z}$ women working remotely in Turkey and intention to quit. The sample of the study consisted of 146 generation $\mathrm{Z}$ women working remotely. Questionnaire was used to collect data. Central tendency and distribution measurements, correlation, ANOVA and t-test were used in data analysis. The averages of the questionnaire responses according to the items, dimensions and variables were interpreted. A weak positive correlation was found between the intention to quit and career path preferences. It has been observed that the employees want to work in the professional field they graduated from, besides, they are open to gain new skills as managers and acquire new competencies in projects.
\end{abstract}


kurumda en önemli girdi konumuna geldikçe kariyer motivasyon kaynağı olarak görülüp önemsenmiştir. Zamanla geleneksel kariyer yaklaşımı yerine çok yönlü kariyer yaklaşımı gündeme gelmiştir. Formal ve dikey yükselmeye sahip olan bir kariyer yaklaşımından bireye ve iş tatminine dayalı yaklaşıma doğru bir yönelim yaşanmıştır (Seymen, 2004, s.81) ve bireyler kendi gelecekleri için kariyerlerini yönlendirme eğilimine girmişlerdir. Çalışanlar gelişimlerine katkı sağlayacak, kariyer fırsatlarını yakalayabilecekleri kurumları tercih etmektedir (Okakın, 2008, s. 139-142). Dolayısıyla kariyer hareketliliği ile ilgili göstergeler kurumlar tarafından dikkate alınmalıdır. Bu göstergelerden birisi Tüz’ün (2003, s. 174) ifade ettiğine göre, kariyer yolu tercihlerinin belirlenmesidir çünkü kariyerindeki ilerlemeden tatmin olmayan çalışanlar işten ayrılma niyeti içerisine girebilirler. Bunun yanı sıra, günümüz iş dünyasında kurumlar kadar bireyler de rekabet etmektedir. Üstelik yeni kuşak bireylerin beklenti, istek ve davranışları ile önceki kuşaklar arasında var olan farklar kariyer yolu tercihlerine doğal olarak yansımaktadır (Çetin ve Karalar, 2016, s.158; Batur ve Adıgüzel, 2014, s.327). Türkiye'de yapılan araştırmalarda kariyer yolunun özellikle 2000'li yıllardan itibaren çalışıldığı görülmektedir. Bu araştırmanın çalışma hayatında farklı bir dönem olan COVID-19 sürecinde Türkiye' de Z kuşağı kadın çalışanların kariyer yolu tercihleri ve işten ayrılma niyetleri ilişkisini ölçerek alanyazına katkı sağlaması umulmaktadır.

\section{KAVRAMSAL ÇERÇEVE}

Latince "yol" anlamına gelen kariyer kavramı, bireylerin kendisini ifade etmesi, yönlendirmesi ve adapte etmesini kapsayan bir süreçtir (Hall, 1996). Kariyerin kurum ve çalışan açısından önemi günden güne artmaktadır. Birey kariyeri ile ilgili nasıl ilerleyeceği konusunda kendisi karar verir ve bu doğrultuda adımlar atarak ilerleme kaydedebilir. Günümüzde belli tek bir işin gerektirdiği bilgi ve beceri yerine, bireyin birden çok iş için kullanılabilecek bilgi ve beceriye sahip olması beklenmektedir. Bu durum, tutum ve davranışları kapsayan yetkinlik ve işe entegre edilmesi gerekliliğini göstermektedir (Erdoğmuş, 2003a, s. 172). Dolayısıyla kariyer kavramını sadece mevcut iş ya da mevcut görevden ibaret görüp sınırlandırmamak önemlidir. Tersi durum kişinin hayatında deneyimlediklerini bütüncül olarak görememeye neden olur.

Kariyer sadece üst düzey çalışanlar ya da hızlı ilerleme firsatı olan işlerde çalışanlar ile ilgili değildir, tüm çalışanlar ile ilgilidir. Bunun yanı sıra, çalışanın sadece dikey değil yatay hareketliliği ve iş tatmini ile de ilgilidir. Çalışanların zaman içerisinde uzman olduğu alanda çalışması olarak ifade edilebilir. Bununla beraber, kariyer tek bir kurumla sınırlanamaz, birçok kurum veya birçok işi kapsayabilir. Ayrıca, kurumun çalışan üstündeki etkileri ile ilgilidir; aynı zamanda çalışanın kendi kariyer planını, hayatını ve denetimini değerlendirmesine imkân sağlar (KSSGM, 2000'den akt., Deniz 2014).

Burack (1988) kariyer değişimine etki eden faktörleri sosyal, kamusal, örgütsel ve bireysel faktörler olarak dört grupta açıklamaktadır. Sosyal faktörler arasında eğitim yoluyla başarının artması, insan ömrünün uzaması, farklı yaş gruplarının nüfus içerisindeki oranlarının değişmesi ve iş olanaklarının fazlalaşması sıralanabilir. Girişimcilerin devlet tarafından teşvik edilmesi ve iş hayatında kadın sayısının artması kamusal faktörler arasında yer almaktadır. Kariyer değişiminde etkili olan örgütsel faktörlerin başında örgütlerde çalışanlara gelişim ve ilerleme imkânlarının sağlanması ile çalışan memnuniyetinin arttırılması vardır. Kişinin çift kariyer düşüncesine sahip olması ve düzen ihtiyacına verdiği önemin artması ise bireysel faktörler olarak belirtilmektedir.

Hem birey hem örgüt açısından yaşanan kariyer süreci, kariyer planlama ve kariyer gelişimini içerir. Kariyer planlama kurum çevresi, yapısı ve işgücü değişimi sonucunda kurumun karşılaşabileceği zorlukları aşmasında yardımcı olmaktadır. Şöyle ki etkili kariyer planlaması çalışanlara yol gösterici olmakta, çalışanların kurumla uyumlu hale getirilmesine katkı sağlamaktadır ve diğer taraftan kurumun da çalışanların beceri ve kapasitelerinden daha iyi yararlanması gerçekleşmektedir (Özgen vd., 2005, s. 203-205). Çalışanların zayıf ve yüksek becerilere sahip olduğu noktaların belirlenmesi ve geliştirme planlarının yapılarak uygulanması önemlidir (Sabuncuoğlu, 2000, s.149). Bireyler planlarını gerçekleştirmek için mevcut çalıştığı işteki durumunu göz önüne alarak harekete geçerler (Acuner, 2019, s.36). Çalışanların beceri, kişilik ve yeteneklerini geliştirebilecekleri sosyal ve teknik donanımlara sahip olma istekleri, kariyerlerini geliştirme beklentileri ve bu beklentiye ulaşma seviyesine göre kariyer yolunda tercih yapmaları söz konusudur.

\subsection{Kariyer Yolu Tercihleri}

Genel olarak kariyer yolu kurumdaki pozisyonların sıralanması şeklinde tanımlanabilir. Çalışanın kariyerini geliştirmek için ne yönde bir hareket ve eylem öngördüğüdür (Türkay ve Eryılmaz, 2010, s.182). Kariyer yolu bireysel açıdan daha fazla bilgi ve deneyim elde ettikçe çalışanın bir kurumdan diğer kurama geçmesi veya bir pozisyondan diğer pozisyona geçmesi anlamındadır. Kurumsal açıdan ise kariyer planlamasının kaynaklarından birisidir ve çalışanlar planlamalarını sağlıklı şekilde yapabilmek için kurumun bilgilendirmesine ihtiyaç duyarlar. Kariyer yolları geleneksel, çift basamaklı, ağ tipi kariyer yolu yaklaşımı ile esnek kariyerli işgücü yaklaşımı olarak dört farklı yaklaşımdan oluşmaktadır. Geleneksel kariyer yolu çalışanın mesleki olarak bir pozisyondan bir diğer pozisyona dikey olarak geçmesidir. Bu geçişte tüm ilerleme net bir şekilde görülür ama alternatif bir alana geçiş mümkün olmadığı için çalışanların kurumsal bağlılıkları, motivasyonları ve iş tatminleri azalır. Çift basamaklı kariyer yolu yaklaşımıyla, çalışanlar uzman olduğu konuda bilgilerini arttırırken kuruma katkı sağlayabilir. 
Günümüzde bürokrasinin olumsuz etkilerini azaltan, çalışanların yaratıcı ve gelişime açık olmalarını sağlayan yaklaşım olarak görülmektedir. Ağ tipi kariyer yolu yaklaşımında dikey ve yatay olarak ilerlemek mümkündür. Esnek kariyerli işgücü yaklaşımında çalışanlar kendilerinin zayıf ve güçlü yönlerini belirleyerek plan yaparlar. Kurum ve çalışan birbirlerine maksimum katkı sağlamış olurlar (Altunışık, 2010, s.35-38).

Kariyer yolları, kariyer planlamasındaki hedefleri gerçekleştirmek için gereken araçları ifade eder (Aytaç, 2005, s. 175). Başarılı sonuç için gelecek işgücünün yapısı bugün çalışmakta olan iş görenlerin kariyer yollarına bağlı olarak gerçekleşeceği için kariyer yolu tercihleri kurum için önemlidir.

Kariyer yolu tercihleri değişim yolu, yeni uzmanlık yolu, alana bağlılık yolu ile aynı alanda yenilik yolu olmak üzere dört boyut olarak incelenmektedir. Değişim yolu, kişinin kariyer planlamasında iş değiştirme, işletme ve sonunda sektör değiştirmeyi öncelikleyen tutumuyla ilgilidir. Yeni uzmanlık yolunun temelinde farklı bir uzmanlık alanında kariyer yapma isteği ve halihazırda çalıştığı alanın dışında yükselme beklentisi yer almaktadır. Alana bağlılık yolunu kendi geleceği için uygun gören kişilerin temel motivasyonu, kendi alanında yönetici olarak kariyerini devam ettirme isteğidir. Aynı alanda yenilik yolunun temel motivasyonu, alandaki işinde kalmak ama yeni projelerde görev almak suretiyle kariyerine devam etme beklentisidir. Tek başına kendi işini kurma isteği bu beklentiyle aynı boyutta yer almıştır. Bu durum, aynı alanda yenilik beklentisinin kendi işini kurma isteği ile birlikte geliştiğini ortaya koymaktadır (Türkay ve Eryılmaz, 2010). Bu araştırmada kariyer yolu tercihleri bu dört boyutta ölçülecektir.

\section{2. İșten Ayrılma Niyeti}

İşten ayrılma niyeti bireyin davranışları ile kurumdan ayrılma düşüncesi içerisinde olduğunu ifade etmektedir (Yıldırım vd. 2014, s.36), birey ayrılma eylemini henüz gerçekleştirmemiştir. İşten ayrılma niyeti faktörleri, çalışanların daha iyi koşullarda iş bulmaları halinde olumlu görülür ama çalışanın işyerinden ayrılması kurum için olumsuz etkiler yaratabilir. Bu etkiler yetenekli personel kaybının yaşanması, yeni personel ihtiyacının doğması nedeniyle işe alım maliyetlerinin artması, diğer çalışanların endişe duymasıdır (Kanten, 2014, s.15). Iverson ve Deery'nin (1997) çalışmasında, iş arama ile önemli ölçüde ilişkili olan işten ayrılma niyetinin kurumsal bağlılık, iş tatmini ve kariyer gelişimi ile negatif ilişkili olduğu belirlenmiştir. Kurumların neredeyse tamamının bu sorun ile karşı karşıya kalması konunun önemini arttırmıştır. Çalışan kurumuna işiyle ilgili tatminsizliğini ya da memnuniyetsizliğini çeşitli şekillerde yansıtmaktadır. Örneğin çalışan düşük verimlilik sergileyerek ya da işe geç kalma davranışını sık tekrarlayarak aslında işaretler vermektedir. İşten ayrılma niyeti çalışanın davranış ve tutumlarıyla gösterdiği bir işaret ve kurumuna yaptığı bir tür uyarı olarak görülmelidir.

İşten ayrılma niyetine etki eden faktörler Kaynak’a (1996) göre, literatürde çalışanlara bağlı faktörler, kuruma bağlı faktörler ve kurum dışı faktörler olarak üç başlık altında açıklanmaktadır. Çalışanlara bağlı olarak işten ayrılma niyetini etkileyen özellikler; yaş, farklı bir işe geçme isteği, bireyin hayatındaki değişimler, iş beklentisi ve psikolojik nedenlerdir. Kuruma bağlı faktörlerin oluşumu ise bireyden kaynaklı değildir ve oluşumu sırasında yönetimin etkisinin fazla olduğu kabul edilir. Kuruluş yeri, kurum yapısı, çalışma şartları, insan kaynakları yönetimi ve kurumsal adalet sistemi bunlar arasındadır. Son faktör grubu olan kurum dışı faktörler de bireysel değildir, sosyal ve ekonomik faktörlerden kaynaklıdır. Kurum dişı faktörlerin önlenmesi oldukça zordur. Bu faktörler örneğin, ilgi çekici farklı işlerin olması, yasalar, vergi yükü, ekonomik sıkıntılar, talep azlığı, mevsimsel değişiklikler, refahın artması ya da azalmasıdır. Heneman vd.'nin (2012) ifadesiyle, çalışanın kuruluşlardan ayrılma niyetinin nedenleri ortak itici güçlerdir. Yüksek işten ayrılma isteği üç ana kategoriye ayrılır. Bunlar düşük iş memnuniyeti, ayrılma kolaylığı (örneğin işgücü piyasasının iyileştirilmesi, düşük ayrılma maliyetinin olması) ve yeni iş teklifidir.

Kurumların personelin işten ayrılma niyeti taşıma noktasına varmamaları konusunda yapabilecekleri vardır. Sanderson'un (2006, s. 92-94) belirttiğine göre, çalışanları işte tutmak ve kuruma bağlılıklarını arttırmak için örneğin, işe alımda yetenek ve davranışlara odaklanan bir sistem oluşturulması, kurallar ve değerlerin kesin olarak belirlenmesi ve uygulanması, çalışanların birbirlerine güven duyduğu bir çalışma ortamının oluşturulması, kişiye özel ödüllendirmelerin yapılması, ücret dışı motive edicilerin belirlenmesi, takımların motivasyonun arttırılması, problem çözümünde kurumdaki herkesin fikrinin alınması sağlanabilir.

\subsection{Z Kuşağı Kadın Çalışanlar}

Toplumdan topluma farklılıklar göstermekle beraber tarihsel süreçte kadına yüklenen cinsiyet rolleri nedeniyle erkek ve kadının çalışma hayatına eşit olarak başlamadığını söylemek mümkündür. Sosyal ve psikolojik araştırmalar belirli örgütsel rollerde ve bağlamlarda kadınların, cinsiyet rolleri ve stereotipleri nedeniyle birçok engelle karşılaştıklarını göstermektedir (Swim vd., 1989).

Yorgun'un (2010, s. 169) ifade ettiği gibi, sanayileşme ile birlikte işgücü ihtiyacı arttıkça kadınlar çalışma hayatına katılmaya başlamıştır. Post modern dönem, bilgi-teknoloji çağı, endüstri 4.0 sürecinde kurum iç ve dış çevresinde yaşanan değişimler 
kadın çalışanların sayısı, erkek çalışanlarla eşit ücret ve eşit haklara sahip olabilmeleri, kadınların çalıştıkları sektörler ve pozisyonlar, kadın yöneticilerin sayısı ve yer aldıkları düzeyler gibi konularda değişimi beraberinde getirmiştir. Diğer taraftan, yeterli olmayan noktalar olduğu görülmektedir. Örneğin Mızrahi ve Aracı'ya (2010) göre, eğitim gören kadınların sayısının artmasıyla kadınların iş hayatındaki yeri artmıştır ama üst düzey pozisyonlarda bulunan kadın sayısının yeterli olduğu söylenemez.

Alanyazın incelendiğinde çalışma hayatında erkeklere oranla kadınlara daha fazla iş yüklendiği görülmektedir (Lyness ve Judiesch, 1999). Ayrıca kadınlar erkeklere göre lider olarak algılanma açısından daha fazla sorunla karşılaşmaktadır (Forsyth vd., 1997). Üstelik kadınlar henüz işe alım süreci aşamasında zorluklar yaşamaktadır (Lyness ve Thompson, 2000) ve daha az ödüllendirilmektedir (Kirchmeyer, 1998). Kadınların ve erkeklerin çalışma özellikleri ve değerleriyle ilgili farklılıkların tespit edildiği Brislin vd.'nin (2005) çalışmasında, işyerinde adil değerlendirmenin kadınların motivasyonu için erkeklere göre daha fazla önemli olduğu sonucu bulunmuştur. Bunun yanı sıra, Curtis vd. (2009) araştırmalarında kadın çalışanlar için erkeklerden daha önemli motive edicilerin iyi çalışma koşulları, iş güvenliği, takdir edilme ve parasal teşvik, terfi ile kariyer gelişimi olduğunu belirlemiştir.

Kadınların erkeklerden çalışma biçimleri ve değerleri açısından farklılıkları olması gibi yine bu noktalarda kuşakların da birbirlerinden farklılıkları vardır. Günümüzde işyerinde beş kuşak vardır: Gelenekçi Kuşak, Bebek Patlaması, X Kuşağı, Y Kuşağ1 ve Z Kuşağı. Z kuşağı olarak nitelendirilen kuşak teknoloji içinde doğan ve büyüyen kuşaktır. Z kuşağı teknolojiye sürekli açtır, girişimcidir ve gelişime açık tutumlar sergiler (Wiedmer, 2015'ten akt., Seymen, 2017, s.472) zaten teknolojik yeniliklere çok hızlı adapte olabilirler (Çaycı ve Karagülle, 2014, s.192). Hayatın her noktasına teknolojiyi yerleştirmek isteyen Z kuşağı Erten'in (2019, s. 191) ifadesiyle, iletişimi de teknoloji yolu ile kurmaktadır. Ayrıca yüksek özgüvene sahiptirler ve gelecekleri konusunda garantici bir tavır sergilerler. Diğer taraftan, Randstad'a (2016) göre, işyerinde Z kuşağı hakkında hala bir bilgi boşluğu olduğu için daha fazla araştırmaya ihtiyaç vardır. Bu konuda temel amaç, yararlı tahminler yapmak, yeni eğilimler oluşturmak ve çalışanların daha iyi yönetilmesine ve liderliğine yardımcı olmak için yeni fikirlerin üretilmesidir.

Bilgi-teknoloji çağı ve endüstri 4.0 sürecinde dünyanın yönünün teknoloji olduğu görülmektedir. Bu koşul içerisinde, teknolojiden anlayan ve yeni teknolojik gelişmelere adapte olabilen Z kuşağının kurumlar için önemi büyüktür. Bu kuşak çalışanlara sahip olmak kurum için rekabet ve sürdürülebilirlik açısından olumlu katkı sağlayabilir. Diğer taraftan, Z kuşağı bireylerin özellikleri kurumları zorlayıcı unsurlar olabilir. Örneğin, Demirdöğmez vd.'nin (2017, s. 1033) belirttiğine göre, Z kuşağı sınırsız bir kariyer düşüncesine sahiptir. Kurumsal bağlılıkları zayıftır. Bu nedenle, kurumların Z kuşağı bireyleri kurumlara çekmek ve kurumda kalmalarını sağlamak için uygun stratejiler geliştirmeleri gereklidir. Bunun için kurumlar Z kuşağı bireylere farklı kariyer olanakları sunmalı ve onlara kariyer yolunda katkı sağlamalıdır.

Kurumların insan kaynağını tanıması gereklidir. Kurum Z kuşağı ve kadın çalışanlara sahip ise onların ihtiyaç ve beklentilerini bilmeli ve buna uygun stratejiler üretmelidir. Aksi halde, çalışanların memnuniyetsizlik duymaları ve kurumsal bağlılığa sahip olmamaları, kariyer yolunda yeni tercihler yaparak işten ayrılmaları gibi sonuçlar gerçekleşebilir.

\subsection{COVID-19 Sürecinde Kariyer Yolu Tercihleri ve İşten Ayrılma Niyeti}

Birey kariyerinin ilerlemesi için kariyerine yön verme kararına sahiptir. Bu ilerleme sadece dikey değil yatay olarak da gerçekleşebilir. Birey yükselmek yerine sadece kendini geliştirmeyi isteyebilir. Yatay ya da dikey ilerlemeden tatmin olmayan çalışanlar ise işten ayrılma niyeti içerisine girebilmektedir (Tüz, 2003). Kariyer yolu hem çalışan birey hem kurum açısından ilerleyen durumlara ilişkin kararların alınmasında önemlidir. Gökdeniz'e (2017) göre, kurumlar çalışanın kariyer yolu eğilimlerine önem verdikçe ve bu doğrultuda çalışanın gelişmesini sağladıkça iş gücü kaybı, zaman ve maliyet kaybı ve verimlilik düşüşü risklerini azaltmaktadır. Aksi durumda, kurumda işten ayrılma sayılarının artması halinde diğer çalışanların performansları bile olumsuz etkilenebilir.

Araştırmanın yapıldığı dönemde COVID-19 pandemi süreci yaşanmaktadır. Süreç içerisinde küresel kriz durumu ortaya çıkmış ve sonucunda işten ayrılma niyetine etki eden ve kurum dışı faktörlerden ekonomik sıkıntı, istihdamda olumsuz etkilenme, talep azlığı, refahın azalması yaşanmıştır. Bireylerin önceliği gelir elde etmektir. Dolayısıyla bu gibi dönemlerde, çalışanın önceliği kurumun sağladığı olanak ve gelişmelerden ziyade sadece halihazırdaki işinde kalmak olabilir. Diğer taraftan, çalışan bu kriz durumunu farklı değerlendirmek de isteyebilir ve kendisi için bir değişim, yeni firsat arama yolunu düşünebilir. Durum çalışanın işten ayrılma niyeti ve kariyer yolu tercihi üzerinde değişimler yaratmaktadır.

Olağan durum içerisinde bile günümüzde çalışanları kurumda tutmak kolay değildir. Çalışanlar artık kendi gelişimlerine açık kurumları tercih etmektedir. Bu beklentinin teknolojiye ve sürekli gelişime açık olan Z kuşağı için doğal olduğunu söylemek mümkündür. Ayrıca kadın çalışanları kurumda tutmak için kadın yöneticilerin sayısının artması gibi gelişme talep edilen konularda kurumların daha fazla ilerleme kaydetmesi gerekmektedir. 


\section{YÖNTEM}

Araştırmanın bu kısmında araştırmanın amacına, örneklemine, hipotezlerine ve veri toplama aracına yer verilmiştir.

\subsection{Araştırmanın Amacı}

Araştırmanın amacı COVID-19 pandemisinde uzaktan çalışan Z kuşağı kadınların kariyer yolu tercihleri ve boyutları ile işten ayrılma niyetleri arasındaki ilişkiyi incelemektir. Bunun yanı sıra araştırmada kariyer yolu tercihleri ve işten ayrılma niyeti demografik değişken etkisine göre de ölçülecektir.

\subsection{Araştırmanın Örneklemi}

Araştırma örneklemi uzaktan çalışan 146 Z kuşağı kadından oluşmaktadır. Z kuşağı kapsamına alınan kişilerin 1995 yılı ve sonrası doğumlu olduğu (Grail Research, 2011) kabulü esas alınmış ve örnekleme sadece 1995 yılı ve sonrasında doğan kadınlar dahil edilmiştir.

\subsection{Araştırmanın Hipotezleri}

Araştırmada test edilecek hipotezler şunlardır:

Hipotez 1: Kariyer yolu tercihleri ile işten ayrılma niyeti arasında pozitif ilişki vardır.

Hipotez 2: Kariyer yolu tercihleri demografik özelliklere göre farklılaşmaktadır.

Hipotez 3: İşten ayrılma niyeti demografik özelliklere göre farklılaşmaktadır.

Hipotez 4: Değişim yolu ile işten ayrılma niyeti arasında pozitif ilişki vardır.

Hipotez 5: Yeni uzmanlık ile ile işten ayrılma niyeti arasında pozitif ilişki vardır.

Hipotez 6: Alana bağlılık ile işten ayrılma niyeti arasında pozitif ilişki vardır.

Hipotez 7: Aynı alanda yenilik ile işten ayrılma niyeti arasında pozitif ilişki vardır.

\subsection{Veri Toplama Aracı}

Ölçüm aracı olarak 5'li likert derecelendirmesini esas alan anket kullanılmış ve internet ortamında uygulanmıştır. Anket formunda, kariyer yolu tercihleri değişkenini ölçmek için Erdoğmuş (2003b) tarafından hazırlanmış, Türkay ve Eryılmaz'ın (2010) çalışmasında uyguladığı on maddeli, "değişim yolu, yeni uzmanlık yolu, alana-bağlılık, aynı alanda yenilik" olarak dört boyuttan oluşan “Kariyer Yolu Tercihleri Ölçeği” kullanılmıştır. İşten ayrılma niyetini tespit etmek için Wayne vd.’in (1997) geliştirdiği, Türkiye'de çeşitli araştırmacılar (örn. Aslan ve Uyar, 2018; Tuna ve Yeşiltaş, 2014) tarafından geçerlilik ve güvenilirliği sağlanmış olan tek boyutlu "İşten Ayrılma Niyeti Ölçeği” kullanılmıştır.

Ölçeğin puan aralığı 5'li likert ölçek genişliğinin derecelendirme sayısına bölünmesiyle bulunmuştur. Buna göre, likert tipi ölçeğin ortalamalarının karşılaştırılmasında, her seçenek için belirlenen puan aralıkları şunlardır: Kesinlikle Katılmıyorum 1.00 - 1.80, Katılmıyorum 1.81 - 2.60, Kararsızım 2.61 - 3.40, Kat1lıyorum 3.41 - 4.20, Kesinlikle Kat1lıyorum 4.21 - 5.00. "Katılıyorum" seçeneğinin alt sınırı olan 3.41 puan aralığı eşik değer olarak belirlenmiştir.

Anket formunda demografik bilgilerle ilgili sorulara da yer verilmiştir. Bunlar çalışanın kurumda çalışma süresi, iş hayatında toplam çalışma süresi, çalışılan bölüm, eğitim durumu, medeni hali ve bakmakla yükümlü olduğu kişi olması durumu maddeleridir.

Verinin analizinde merkezi eğilim ve dağılım ölçümleri, SPSS programında korelasyon, ANOVA ve t-testi yapılmıştır. Elde edilen bulgular tablolar halinde sunulmuştur.

\section{BULGULAR}

Araştırmada güvenilirlik katsayısı $\alpha=0.815$ olarak bulunmuştur, buna göre araştırma örnekleminde ölçüm güvenilirdir. Demografik değişkenlere ilişkin sıklık ve yüzde sonuçları Tablo 1'de gösterilmiştir. 
Tablo 1. Demografik Değişkenlere İlişkin Sıklık (f) ve Yüzde (\%) Değerleri

\begin{tabular}{|c|c|c|c|}
\hline Demografik Değişkenler & Cevaplar & $\mathbf{f}$ & $\%$ \\
\hline \multirow{3}{*}{ Kurumda Çalışma Süresi } & 1 Yildan $\mathrm{Az}$ & 48 & 32,9 \\
\hline & 1-4 Y1l & 82 & 56,2 \\
\hline & $5-9$ Yil & 16 & 11,0 \\
\hline \multirow{3}{*}{ Toplam Çalıșma Süresi } & 1 Yildan $\mathrm{Az}$ & 26 & 17,8 \\
\hline & $1-4 Y_{11}$ & 83 & 56,8 \\
\hline & $5-9$ Yil & 37 & 25,3 \\
\hline \multirow{5}{*}{ Çalışılan Bölüm } & Üretim & 18 & 12,3 \\
\hline & Pazarlama & 17 & 11,6 \\
\hline & Yönetim & 18 & 12,3 \\
\hline & Muhasebe/Finans & 39 & 26,7 \\
\hline & Diğer & 54 & 37 \\
\hline \multirow{4}{*}{ Eğitim Durumu } & Lise & 18 & 12,3 \\
\hline & Lisans & 111 & 76,0 \\
\hline & Yüksek lisans & 13 & 8,9 \\
\hline & Doktora & 4 & 2,7 \\
\hline \multirow{2}{*}{ Medeni Durum Özellikleri } & Bekar & 109 & 74,7 \\
\hline & Evli & 37 & 25,3 \\
\hline \multirow{2}{*}{$\begin{array}{l}\text { Bakmakla Yükümlü } \\
\text { Kişi/Kişilerin Olması }\end{array}$} & Var & 39 & 26,7 \\
\hline & Yok & 107 & 73,3 \\
\hline Toplam & & 146 & 100 \\
\hline
\end{tabular}

Tablo 1'e göre, örneklem 146 kişidir ve örneklemde 82 katılımcı yani örneklemin yarısından fazlası 1-4 yıldır, 48 katılımcı 1 yıldan az süredir, 16 katılımcı ise 5-9 yıldır şimdiki kurumlarında çalışmaktadır. 83 katılımcı 1-4yıl arası çalışma deneyimine sahiptir. Üretim bölümünde çalışan ve yönetim bölümünde çalışan katılımcı sayıları eşit ve 18, pazarlama bölümünde çalışan katılımcı sayıs1 17, muhasebe/finans bölümünde çalışan katılımcı sayısı 39'dur. 54 katılımc1 ise "Diğer" bölümde görev yaptığını belirtmiştir. Lisans mezunu katılımcı sayısı 111 kişidir. Ayrıca lisansüstü eğitim almış -yüksek lisans ve doktora mezunu- toplam 17 kişi vardır. Araştırmaya katılan 146 kişiden 109'u bekardır. Bakmakla yükümlü olduğu kişi olmadığını belirtenlerin say1s1 107'dir.

Araştırma değişkenleri, boyutları ve soru maddelerine ilişkin betimsel analizler yapılmış, genel ortalama ve standart sapmalar sırasıyla Tablo 2'de ve Tablo 3'te gösterilmiştir.

Tablo 2. Araştırma Değişkenlerine İlişkin Ortalama (M) ve Standart Sapma (SS) Değerleri

\begin{tabular}{lcc}
\hline Değişkenler ve Boyutlar & M & SS \\
\hline Kariyer Yolu Tercihleri & 3,291 & 1,604 \\
\hline Değişim Yolu & 2,883 & 1,510 \\
\hline Yeni Uzmanlık Yolu & 3,041 & 1,570 \\
\hline Alana- Bağlılık Yolu & 3,958 & 1,330 \\
\hline Aynı-Alanda Yenilik Yolu & 3,420 &, 991 \\
\hline İşten Ayrılma Niyeti & 3,201 & 1,719 \\
\hline
\end{tabular}

Tablo 2'ye göre, kariyer yolu tercihleri ve işten ayrılma niyeti değişkenlerine göre katılımcı yanıtlarının ortalamaları "Kararsızım" aralığındadır. Kariyer yolu tercihleri boyut ortalamalarına bakıldığında, çalışanlar iki boyutta (alana bağlılık yolu ile aynı alanda yenilik yolu) "Katılıyorum" tercihi yapmıştır.

Tablo 3. Soru Maddelerine İlişkin Ortalama (M) ve Standart Sapma (SS) Değerleri

\begin{tabular}{|c|c|c|c|c|}
\hline Değişken & Boyutlar & Soru (S) & $\mathbf{M}$ & SS \\
\hline \multirow{11}{*}{$\begin{array}{l}\text { Kariyer Yolu } \\
\text { Tercihleri }\end{array}$} & \multirow{3}{*}{$\begin{array}{l}\text { KY Boyut1: Değişim } \\
\text { Yolu }\end{array}$} & $\mathrm{S} 1$ & 2,890 & 1,758 \\
\hline & & $\mathrm{S} 2$ & 3,109 & 1,661 \\
\hline & & S3 & 2,650 & 1,708 \\
\hline & \multirow{2}{*}{$\begin{array}{l}\text { KY Boyut2: Yeni } \\
\text { Uzmanlık Yolu }\end{array}$} & $\mathrm{S} 4$ & 2,917 & 1,687 \\
\hline & & S5 & 3,164 & 1,722 \\
\hline & \multirow{2}{*}{$\begin{array}{l}\text { KY Boyut3: Alana } \\
\text { Bağlılık Yolu }\end{array}$} & S6 & 3,650 & 1,569 \\
\hline & & S7 & 4,267 & 1,366 \\
\hline & \multirow{3}{*}{$\begin{array}{l}\text { KY Boyut4: Aynı } \\
\text { Alanda Yenilik Yolu }\end{array}$} & S8 & 3,520 & 1,340 \\
\hline & & S9 & 3,815 & 1,504 \\
\hline & & $\mathrm{S} 10$ & 2,924 & 1,669 \\
\hline & İAN Tek Boyut & S11 & 3,431 & 1,803 \\
\hline
\end{tabular}


İşten Ayrılma Niyeti

\begin{tabular}{lll}
$\mathrm{S} 12$ & 3,267 & 1,657 \\
\hline $\mathrm{S} 13$ & 3,075 & 1,789 \\
\hline $\mathrm{S} 14$ & 3,123 & 1,761 \\
\hline $\mathrm{S} 15$ & 3,109 & 1,571
\end{tabular}

Tablo 3'e göre, çalışanların kariyer yolu tercihleri alana bağlılık boyutunda "Mezun olduğum bölümle ilgili mesleki alanda yöneticilik...(S6)" ölçek maddesinde yanıtların ortalaması 3.650'dir; "Mezun olduğum bölümle ilgili mesleki alanda çalışmak...(S7)" maddesinde yanıtların ortalaması 4,267'dir. Bu ifadeler aslında katılımcıların kariyer yolu tercihlerinin mezun oldukları mesleki alanlarında, başka bir ifadeyle uzmanı oldukları alanda çalışmak ve/veya çalışmaya devam etmek istediklerini göstermektedir. Aynı alanda yenilik boyutundaki iki maddede yanıtların ortalaması "Katılıyorum" görüşündedir. Burada "Şu an çalıştığım işte yükselmek istiyorum (S9)" ölçek maddesinde yanıtların ortalaması 3,815'tir; "Terfi etmeden yenilik içeren...(S8)" maddesinde yanıtların ortalaması 3,520'dir. Buna göre, katılımcıların çalışmakta oldukları işte yükselmek bir anlamda yeni becerileri kullanabilecekleri bir pozisyona geçmek ya da aynı pozisyonda yenilik içeren projelerde çalışarak yeni şeyler yapmak istedikleri söylenebilir.

İşten ayrılma niyeti ile ilgili maddelerin ortalamaları incelendiğinde, "Daha iyi bir iş bulur bulmaz...(S11)" maddesinin ortalaması 3,431 ile "Katılıyorum" yönünde olmuştur. "Önümüzdeki 5 yıl daha...(S15)" maddesinin ortalaması 3,109 ile "Kararsızım" aralığındadır. Ayrıca değişim yolu ve yeni uzmanlık boyutlarında soru maddeleri düzeyinde ortalamalar yine "Kararsızım" aralığındadır. Genel olarak, işten ayrılma değişkeni ortalaması "Kararsızım” aralığını gösterse bile, madde düzeyinde bakıldığında çalışanların işten ayrılma niyetlerinin kritik bir eşikte olduğu görülebilir.

Değişkenlere ilişkin katılımcı görüşlerinin demografik özelliklere göre farklılık gösterip göstermediğinin belirlenmesi için analizler yapılmıştır. Hipotez 2 (Kariyer yolu tercihleri demografik özelliklere göre farklılaşmaktadır) ve Hipotez 3 (İşten ayrılma niyeti demografik özelliklere göre farklılaşmaktadır) kabul edilmiştir.

Medeni durum ve bakmakla yükümlü olunan bir kişinin olması özellikleri için t-test analizi; kurumda çalışma süresi, toplam çalışma süresi, çalışılan bölüm ve eğitim durumu özellikleri için ise ANOVA yapılmıştır.

Kariyer yolu tercihleri boyutlarından alana-bağlılık yolu boyutunda bekar ve evli katılımcıların görüşlerinin ortalamaları arasında istatistiksel anlamlı fark bulunmuştur. Alana bağlılık konusunda bekar çalışanların $(\mathrm{M}=4,027)$ evli çalışanlara $(\mathrm{M}=3,756)$ göre daha kati görüşe sahip oldukları görülmektedir $(\mathrm{F}=5,751, \mathrm{p}=, 018)$, bekar çalışanların mesleki alanı daha fazla önemsediği söylenebilir.

Katılımcıların işten ayrılma niyeti hakkındaki görüşlerinin bakmakla yükümlü kişinin olması özelliğine göre ortalama fark sınaması yapılmış ve istatistiksel olarak anlamlı fark olduğu belirlenmiştir. Başkasına bakmakla yükümlü olduğunu belirten çalışan grubunun $(\mathrm{M}=2,759)$ diğer gruba göre $(\mathrm{M}=3,362)$ işten ayrılma niyetinin düşük olduğu $(\mathrm{F}=6,938, \mathrm{p}=, 009)$ görülmüştür.

Tek yönlü ANOVA analizi sonucunda, aynı-alanda yenilik yolu boyutu için iş yaşamındaki toplam çalışma süresi 1-4 yıl olan katılımcılar ile 5-9 yıl olan katılımcıların görüşleri arasında istatistiksel anlamlı fark olduğu belirlenmiştir. Toplam çalışma süresi 5-9 yıl olan grubun $(M=3,964) 1-4$ y1l olan gruba $(M=3,228)$ göre aynı alanda yenilik isteği yüksektir $(F=8,211$, $\mathrm{p}=, 000)$.

İşten ayrılma niyeti hakkındaki görüşlerin katılımcıların eğitim durumuna göre farklı olup olmadığını belirlemek amacıyla tek yönlü ANOVA testi yapılmıştır. Analiz sonucunda eğitim düzeyi doktora olan katılımcılar ile diğer gruplar arasında işten ayrılma niyeti açısından istatistiksel olarak anlamlı farklılık olduğu belirlenmiştir. Diğer grupların verdikleri yanıtlar kararsız oldukları yönündedir, eğitim düzeyi doktora olan kişilerin işten ayrılma niyetlerinin ise yüksek olduğu $(\mathrm{M}=4,90)$ belirlenmiştir.

Aynı alanda yenilik yolu değişkeni için katılımcıların eğitim durumuna göre farklı olup olmadığını belirlemek amacıyla tek yönlü ANOVA testi yapılmıştır. Buna göre, aynı alanda yenilik yolu görüşleri lise mezunu katılımcılar ile lisans, yüksek lisans ve doktora mezunu grupların her biri arasında anlamlı farklılık göstermektedir. Diğer grupların verdikleri yanıtlar kararsız oldukları yönündedir, eğitim düzeyi lise olan kişilerin ise aynı alanda yenilik isteğinin "Kesinlikle Katılıyorum" yönünde olduğu $(\mathrm{M}=4,425)$ görülmektedir.

Değişkenler ve boyutlar arasındaki ilişkileri ölçmek amacıyla korelasyon analizi yapılmış ve sonuçlar sırasıyla Tablo 4 ve Tablo 5'te verilmiştir $(* \mathrm{p}<.05, * * \mathrm{p}<.01)$. 
Tablo 4. Kariyer Yolu Tercihleri ile İşten Ayrılma Niyetine İlişkin Korelasyon Analizi

\begin{tabular}{lccc}
\hline & & Kariyer Yolu Tercihleri & Isşten Ayrılma Niyeti \\
\hline Kariyer Yolu Tercihleri & $\mathrm{r}$ & 1 &, $167^{*}$ \\
\cline { 2 - 4 } & $\mathrm{p}$ & &, 044 \\
\hline İşten Ayrılma Niyeti & $\mathrm{r}$ &, $167^{*}$ & 1 \\
\cline { 2 - 4 } & $\mathrm{p}$ &, 044 & 1 \\
\hline
\end{tabular}

Tablo 4'te korelasyon sonuçları ilişki düzeylerine göre (Cohen, 1988'den akt., Pallant, 2005, s. 126) yorumlandığında, kariyer yolu tercihleri ile işten ayrılma niyeti arasında pozitif yönde zayıf (.167) ilişki olduğu görülmektedir. Buna göre, Hipotez 1 (Kariyer yolu tercihleri ile işten ayrılma niyeti arasında pozitif ilişki vardır) kabul edilmiştir.

Tablo 5. Kariyer Yolu Tercihleri Boyutları ile İşten Ayrılma Niyetine İlişkin Korelasyon Analizi

\begin{tabular}{|c|c|c|c|c|c|c|}
\hline & & Değişim Yolu & $\begin{array}{l}\text { Yeni Uzmanlık } \\
\text { Yolu }\end{array}$ & $\begin{array}{l}\text { Alana- Bağlılık } \\
\text { Yolu }\end{array}$ & $\begin{array}{l}\text { Aynı-Alanda } \\
\text { Yenilik Yolu }\end{array}$ & $\begin{array}{l}\text { İşten Ayrılma } \\
\text { Niyeti }\end{array}$ \\
\hline \multirow[t]{2}{*}{ Değișim Yolu } & $\mathrm{R}$ & 1 &, $769 * *$ &, $434 * *$ & ,267** & ,215** \\
\hline & $\mathrm{P}$ & &, 000 &, 000 & ,001 & ,009 \\
\hline \multirow{2}{*}{$\begin{array}{l}\text { Yeni Uzmanlık } \\
\text { Yolu }\end{array}$} & $\mathrm{R}$ &, $769 * *$ & 1 & ,297** &, $217 * *$ &, $212 *$ \\
\hline & $\mathrm{P}$ & ,000 & &, 000 & ,009 & 010 \\
\hline \multirow{2}{*}{$\begin{array}{l}\text { Alana- Bağlılık } \\
\text { Yolu }\end{array}$} & $\mathrm{R}$ &, $434 * *$ & ,297** & 1 & ,244** &, 152 \\
\hline & $\mathrm{P}$ &, 000 &, 000 & & ,003 &, 068 \\
\hline \multirow{2}{*}{$\begin{array}{l}\text { Aynı-Alanda } \\
\text { Yenilik Yolu }\end{array}$} & $\mathrm{R}$ & ,267** &, $217 * *$ & ,244** & 1 &,$- 129 *$ \\
\hline & $\mathrm{P}$ &, 001 &, 009 &, 003 & &, 121 \\
\hline \multirow{2}{*}{$\begin{array}{l}\text { İşten Ayrılma } \\
\text { Niyeti }\end{array}$} & $\mathrm{R}$ &, $215^{* *}$ &, $212^{*}$ & ,152 &,$- 129 *$ & 1 \\
\hline & $\mathrm{P}$ & ,009 & ,010 & ,068 &, 121 & \\
\hline
\end{tabular}

Tablo 5'e göre, işten ayrılma niyeti ile değişim yolu arasında zayıf pozitif ( $\mathrm{r}=0.215)$, yeni uzmanlık yolu ile arasında zayıf pozitif ( $\mathrm{r}=0.212)$, aynı alanda yenilik yolu ile arasında ise zayıf negatif $(\mathrm{r}=-0.129)$ ilişki görülmektedir. Boyutlar arasındaki en yüksek ilişki pozitif yönde yeni uzmanlık yolu ile değişim yolu boyutları arasındadır, bu boyutlar arasında güçlü pozitif $(\mathrm{r}=0.769)$ ilişki vardır. Hipotez 4 (Değişim yolu ile işten ayrılma niyeti arasında pozitif ilişki vardır) ve Hipotez 5 (Yeni uzmanlık ile ile işten ayrılma niyeti arasında pozitif ilişki vardır) kabul edilmiş ve Hipotez 7 (Aynı alanda yenilik ile işten ayrılma niyeti arasında pozitif ilişki vardır) reddedilmiştir. İşten ayrılma niyeti ile alana-bağlılık yolu boyutunda anlamlı ilişki bulunamadığı için Hipotez 6 reddedilmiştir.

\section{SONUÇ}

Çalışanlar kariyer yolu tercihi yaparken içinde bulundukları çevre koşullarını dikkate alırlar ve kariyer yolu hedeflerine göre işten ayrılma niyeti hissedebilirler. Çalışanların işte kalmayı seçmelerine ya da işten ayrılmalarına neden olan faktörler vardır. Bunlar Kaynak (1996) ve Heneman vd.'nin (2012) belirttiği gibi çalışanın kendisine bağlı faktörler olabildiği gibi kuruma bağlı faktörler ve kurum dışı faktörler de olabilir. Eğer çalışan kişi istek ve beklentilerini çalıştı̆̆ kurumda karşılayamıyorsa, iş tatminsizliği, düşük kurumsal bağl1lık hissetme, düşük verimlilik sergileme ve kurumdan ayrılma niyeti görülmektedir.

COVID-19 pandemisi yaşamın birçok alanını etkilemiştir. Pandemi sürecinde küresel kriz durumu ortaya çıkmış ve işten ayrılma niyetine etki eden kurum dışı faktörlerden olan ekonomik sıkıntı, istihdamda olumsuz etkilenme, talep azlığı, refahın azalması yaşanmıştır. Öncelik temel ihtiyaçları karşılamak olduğu için çalışanların isteği mevcut işlerini koruyarak gelir elde etmektir. Diğer taraftan, çalışanlar kriz durumunu farklı değerlendirmek isteyebilirler ve kendileri için bir değişim gerçekleştirme ve yenilik yakalama yolunu düşünebilirler. Durum çalışanın işten ayrılma niyeti ve kariyer yolu tercihi üzerinde değişimler yaratmaktadır.

Teknoloji içine doğanlar olarak nitelendirilen Z kuşağı bireyler çalışma hayatında yerlerini almaya başlamıştır. Bu kuşağın sahip olduğu farklılıkların alanyazındaki kariyer hedefleri ve gelişimini değiştirmesi beklenmektedir. Ayrıca iş yaşamında kadınların sayısı artmaktadır ancak onların kariyer yolu tercihlerine etki eden işyerlerindeki sorunları halen devam etmektedir. Dolayısıyla kurumların, çalışma hayatında yer almakta olan ve gelecekte bunu sürdürecek olan Z kuşağının ve kadınların beklentilerini anlamaları gereklidir. $\mathrm{Bu}$ sayede, stratejiler geliştirmeleri mümkün olabilir. Bu doğrultuda araştırmanın amacı Türkiye'de uzaktan çalışan Z kuşağı kadınların kariyer yolu tercihleri ile işten ayrılma niyetleri arasındaki ilişkiyi incelemektir. Araştırma örneklemi uzaktan çalışan 146 Z kuşağı kadından oluşmuştur. Ölçüm aracı olarak anket kullanılmıştır.

Katılımcıların hem kariyer yolu tercihleri görüşü hem işten ayrılma niyeti görüşü "Kararsızım” ölçek puan aralığındadır. Çalışanların işlerinde kalma ya da işlerinden ayrılma konusunda kararsız oldukları görülmektedir. Madde düzeyinde bakıldığında çalışanların işten ayrılma niyetlerinin kritik eşikte olduğu söylenebilir. Şöyle ki "daha iyi bir iş bulur bulmaz çalıştı̆̆ım işletmeden ayrılacağım” maddesinin ortalaması "Katılıyorum” (M=3,431) yönündedir. 
Kariyer yolu tercihleri değişkeninin alana bağlılık yolu boyutu ile aynı alanda yenilik yolu boyutunda çalışanlar "Katılıyorum" tercihi yapmıştır. Katılımcıların kariyer yolu tercihlerinin mezun oldukları mesleki alanlarında çalışmak ve/veya çalışmaya devam etmek olduğu görülmüştür. Aynı alanda yenilik boyutunda ise katılımcıların yanıtları çalışmakta oldukları işte yükselerek yeni becerileri kullanabilecekleri bir pozisyona geçmek ya da aynı pozisyonda yenilik içeren projelerde yer almak yönünde olmuştur.

Katılımcı görüşlerinin demografik özelliklere göre farklılık gösterip göstermediğinin belirlenmesi için t-test analizi ve ANOVA yapılmıştır. Alana-bağlılık yolu boyutunda bekâr ve evli katılımcıların görüşlerinin ortalamaları arasında istatistiksel anlamlı fark bulunmuştur. Buna göre, alana bağlılık konusunda bekâr çalışanların evli çalışanlara göre daha kesin görüşe sahip oldukları başka bir ifadeyle bekâr çalışanların mesleki alanı daha fazla önemsediği söylenebilir. Ayrıca, başkasına bakmakla yükümlü olduğunu belirten çalışan grubunun işten ayrılma niyeti başkasına bakma yükümlülüğü olmayan gruba göre daha düşüktür. Burada çalışanların bakmakla yükümlü olduğu kişilere karşı sorumluluklarını yerine getirmek için mevcut işlerine sahip çıkma önceliğinde oldukları söylenebilir.

Korelasyon analizlerine göre, işten ayrılma niyeti ile sırasıyla kariyer yolu tercihleri, değişim yolu ve yeni uzmanlık yolu arasında zayıf pozitif ilişki, aynı alanda yenilik yolu ile arasında ise zayıf negatif ilişki görülmektedir. Boyutlar arasındaki en yüksek ilişki pozitif yönde yeni uzmanlık yolu ile değişim yolu boyutları arasındadır.

İş yaşamındaki toplam çalışma süresi 5-9 yıl olan grubun 1-4 yıl olan gruba göre aynı alanda yenilik isteği yüksektir.

İşten ayrılma niyeti açısından eğitim düzeyi doktora olan katılımcılar ile diğer gruplar arasında istatistiksel olarak anlamlı farklılık vardır. Diğer grupların verdikleri yanıtlar kararsız oldukları yönündedir, eğitim düzeyi doktora olan kişilerin işten ayrilma niyetleri ise diğer gruplardan yüksektir.

Aynı alanda yenilik yolu görüşleri lise mezunu katılımcılar ile lisans, yüksek lisans ve doktora mezunu grupların her biri arasında anlamlı farklılık göstermiştir. Diğer grupların verdikleri yanıtlar kararsız oldukları yönündedir, eğitim düzeyi lise olan kişilerin ise aynı alanda yenilik isteğinin yüksek olduğu görülmüştür.

Özetle, anket yanıtlarının madde, boyut ve değişkenlere göre ortalamaları incelendiğinde, çalışanların mezun oldukları yani eğitim aldıkları mesleki alanda çalışmak istedikleri, bununla beraber yönetici olarak yeni beceriler kazanmaya ve projelerde yeni yeterlilikler edinmeye açık oldukları görülmektedir. Ayrıca kariyer yolunda "daha iyi bir iş bulur bulmaz çalıştıkları işletmeden ayrılmayı" da düşünmektedirler. Z kuşağı kadın çalışanların kariyer yolu tercihleri ile işten ayrılma niyeti arasında pozitif yönde zayıf ilişki vardır. Kurumların Z kuşağı kadın çalışanların görüş ve isteklerini hızlı şekilde anlamaları gereklidir. Şöyle ki bugün için Z kuşağı kadın çalışanlar iş yaşamında henüz etkilerini tam olarak yansıtmamış olabilirler; ancak çalışanların motivasyon ve verimliliklerini arttırmalarını ve kurumda kalmalarını sağlamak için şimdiden çalışmaya başlayan kurumlar yakın gelecekte önde olacaktır. Dolayısıyla işletmelerin bu konuda uygun strateji ve uygulamalar geliştirmeleri hem kurumun hem çalışanların geleceği açısından önem taşımaktadır.

\section{KAYNAKÇA}

Acuner, Ş.A. (2019). Kadın Çalışanların Kariyer Geliştirme Sürecinde Karşılaştıkları Sorunlar. Uluslararası İktisadi ve İdari İncelemeler Dergisi, $23(35), 35-52$

Adıgüzel, O. (2009). Shein'ın Kariyer Çapaları Perspektifinde Süleyman Demirel Üniversitesi İiBF Öğrencilerinin Kariyer Değerlerine İlişkin Bir Araștırma. Süleyman Demirel Üniversitesi İ̈BF Dergisi, 14 (2), 277-292.

Altunışık, B. (2010). Öğretmenlerin Kariyer Hedeflerinin Eğitim Kurumlarındaki Kariyer Yönetimi Uygulamalarına Yansıması Üzerine Öğretmen Algıları. (Yüksek Lisans Tezi, Selçuk Üniversitesi Eğitim Bilimleri Enstitüsü, Konya). http://tez2.yok.gov.tr/ adresinden edinilmiştir.

Aslan,Ş. ve Uyar, S.(2018). Psikolojik sözleşme ihlali ile hissettirdiklerinin örgütsel özdeşleşme, iş tatmini ve işten ayrılma niyeti üzerine etkileri. Dokuz Eylül Üniversitesi İktisadi İdari Bilimler Fakültesi Dergisi, 33(1), 1-38.

Aytaç, S. (2005). Çalısma Yaşamında Kariyer Yönetimi Planlaması ve Sorunları. Bursa: Ezgi Kitabevi.

Brislin, R. W., MacNab, B., Worthley, R., Kabigting, F., \& Zukis, B. (2005). Evolving Perceptions of Japanese Workplace Motivation. International Journal of Cross Cultural Management, 5(1), 87-104. Doi: 10.1177/1470595805050829

Burack, E.H. (1988). Career Management in Organisations: A Practical Human Resources Planning, Brace-Park Press Lake Forest, IL.

Curtis, C. R., Upchurch, R. S., \& Severt, D. E. (2009). Employee Motivation and Organizational Commitment: A Comparison of Tipped and Nontipped Restaurant Employees. International Journal of Hospitality \& Tourism Administration, 10(3), 253-269. Doi: $10.1080 / 15256480903088469$

Çaycı, B., \& Karagülle, A. (2014). X Kuşağından Z Kuşağına Değişen Mahremiyet Algıssı. International Trends and Issues in Communication \& Media Conference, (s. 190-196). İstanbul.

Demirdöğmez, M., Küçükoğlu, M. ve Taş, H. (2017). Geleceğimiz Olan Z Kuşağının Çalışma Hayatına Muhtemel Etkileri. OPUS Uluslararası Toplum Araştırmaları Dergisi, 7(13), 1033-1047.

Deniz, A.C. (2014). Çalışma Yaşamında Kariyer Kavramı Kapsamında Kadınlara Yönelik Cinsiyet Ayrımcılığı. (Yüksek Lisans Tezi, Yaşar Üniversitesi Sosyal Bilimler Enstitüsü, İzmir). http://tez2.yok.gov.tr/ adresinden edinilmiştir.

Erdoğmuş, N. (2003a). Kariyer Geliștirme. Ankara: Nobel Akademik Yayıncılık Eğitim Danıșmanlık.

Erdoğmuş, N. (2003b). "Profesyonel İşgörenlerin Yönetsel Kariyer Tercihleri: Amprik Bir Araştırma", 11. Ulusal Yönetim ve Organizasyon Kongresi, 24-26 Mayis 2003, Afyon.

Erten, P. (2019). Z Kuşağının Dijital Teknolojiye Yönelik Tutumları. Gümüşhane Üniversitesi Sosyal Bilimler Enstitüsü Elektronik Dergisi, 1(10), 190-202. 
Forsyth, D.R., Heiney, M. I., \& Wright, S. S., (1997). Biases in Appraisals of Women Leaders.Group Dynamics: Theory, Research, and Practice, 1(1), 98-103. Doi: 10.1037/1089-2699.1.1.98

Gökdeniz, İ. (2017). Özel Sektör ve Kamu Yönetiminde Kariyer Planlaması. KMÜ Sosyal ve Ekonomik Araştırmalar Dergisi, 19(32), 123-131.

Grail Research (2011). A Division of Integreon. Consumers of Tomorrow: Insights and Observations about Generation Z. Retrieved from: https://docplayer.net/31078434-Consumers-of-tomorrow.html

Hall, D. T. (1996). Protean Careers of The 21st Century. Academy of Management Executive, 10(4), 8-16. Doi: 10.5465/ame.1996.3145315

Heneman, H. G., Judge, T. A., \& Kammeyer-Mueller, J. D. (2012). Staffing Organizations (7th ed.). New York, NY: McGraw Hill.

Iverson, R. D., \& Deery, M. (1997). Turnover Culture in the Hospitality İndustry. Human Resource Management Journal, 7(4), 71-82. Doi: 10.1111/j.1748-8583.1997.tb00290.x

Kanbur, A. ve Salihoğlu, G. (2014). Çalışanların Sınırsız ve Değişken Kariyer Yolculuğunda İşkolikliğin Rolü Üzerine Bir Araştırma. Manas Sosyal Araştırmalar Dergisi , 3 (2), 27-58.

Kanten, P. (2014). İsyeri Nezaketsizliğinin Sosyal Kaytarma Davranıșı ve İșten Ayrılma Niyeti Üzerindeki Etkisinde Duygusal Tükenmenin Aracılık Rolü. Aksaray Üniversitesi İktisadi ve İdari Bilimler Fakültesi Dergisi, 6(1), 6-26.

Kaynak, T. (1996). İnsan Kaynakları Planlaması. İstanbul: Alfa Basım Yayım Dağıtım.

Kirchmeyer, C. (1998). Determinants of Managerial Career Success: Evidence and Explanation of Male/Female Differences. Journal of Management, 24(6), 673-692. Doi: 10.1177/014920639802400601

Lyness, K.S., \& Thompson, D. E. (2000). Climbing The Corporate Ladder: Do Female and Male Executives Follow The Same Route? Journal of Applied Psychology, 85(1), 86-101. Doi: 10.1037/0021-9010.85.1.86

Lyness, K.S., \& Judiesch, M.K. (1999). Are Women More Likely to Be Hired or Promoted into Management Positions? Journal of Vocational Behavior, 54, 158-173. Doi: 10.1006/jvbe.1998.1646

Mızrahi, R. ve Aracı, H. (2010). Kadın Yöneticiler ve Cam Tavan Sendromu Üzerine Bir Araştırma, Organizasyon ve Yönetim Bilimleri Dergisi, 2(1), $149-156$.

Okakın, N. (2008). Çalışma Yaşamında İnsan Kaynakları Yönetimi. İstanbul: Beta Basım Yayın.

Özgen, H., Öztürk, A., \& Yalçın, A. (2005). Insan Kaynakları Yönetimi. Adana: Nobel Kitabevi.

Pallant, J. (2005). SPSS Survival Manual: A Step by Step Guide to Data Analysis Using SPSS for Windows (Version 12). Open University Press.

Randstad. (2016). Gen Z and Millennials collide at work.Retrieved from www.randstadusa.com

Sabuncuoğlu, Z. (2000). İnsan Kaynakları Yönetimi. Bursa: Ezgi Kitabevi Yayınları.

Sanderson, P. A. (2006). The Relationships Between Empowerment and Turnover Intentions in a Structured Environment: An Assessment of the Navy's Medical Service Corps. Regent University, School of Leadership Studies.

Seymen, A. F. (2017). Y ve Z Kuşak İnsanı Özelliklerinin Milli Eğitim Bakanlığı 2014-2019 Stratejik Programı ve TÜBITTAK Vizyon 2023 Öngörüleri ile İliş̧ilendirilmesi. Kent Kültürü ve Yönetimi Hakemli Elektronik Dergi, 10(4), 467-489.

Seymen, O.A. (2004). Geleneksel Kariyerlerden, Sinırsız ve Dinamik/ Değişen Kariyere Geçiş: Nedenleri ve Sonuçları Üzerine Yazınsal Bir İnceleme. Uludağ Üniversitesi İktisadi ve İdari Bilimler Fakültesi Dergisi, 23(1), 79-114.

Swim, J., Borgida, E., Maruyama, G., \& Myers, D. (1989). Joan Mckay Versus John Mckay: Do Gender Stereotypes Bias Evaluations? Psychological Bulletin, 105(3), 409-429. Doi: 10.1037/0033-2909.105.3.409

Şimşek, M. Ş., Çelik, A., Akgemci, T., \& Soysal, A. (2004). Kariyer Yönetimi. Ankara: Gazi Kitabevi.

Tuna, M. ve Yeşiltaş, M. (2014). Etik İklim, İşe Yabancılaşma ve Örgütsel Özdeşleşmenin İşten Ayrılma Niyeti Üzerindeki Etkisi: Otel İşletmelerinde Bir Araștırma. Anatolia: Turizm Araștırmaları Dergisi, 25(1), 105-117.

Türkay, O. ve Eryılmaz, B. (2010). Kariyer Değerleri ve Kariyer Yolu Tercihleri İlişkisi: Türk Turizm Sektöründen Örnekler. Muğla Üniversitesi Sosyal Bilimler Enstitüsü Dergisi, 24, 179-199.

Tüz, M. V. (2003). Kariyer Planlamasında Yeni Yaklaşımlar. Uludă̆ Üniversitesi Fen- Edebiyat Fakültesi Sosyal Bilimler Dergisi, 4(4), 169-176.

Wayne, S., Shore, L., \& Liden, R. (1997). Perceived Organizational Support and Leader-Member Exchange: A Social Exchange Perspective. The Academy of Management Journal, 40(1), 82-111. Retrieved from http://www.jstor.org/stable/257021.

Yıldırım, M., Erul, E. ve Kelebek, P. (2014). Tükenmişlik ile İșten Ayrılma Niyeti Arasındaki İlişki Banka Çalışanları Üzerine Bir Araştırma. Organizasyon ve Yönetim Bilimleri Dergisi, 6(1), 34-44.

Yorgun, S. (2010). Sömürü,Koruma ve Pozitif Ayrımcılıktan Çalışma Hayatının Egemen Gücü Olmaya Doğru Kadınlar: 21. Yüzyıl ve Pembeleşen Çalışma Hayatı. Sosyo- Ekonomi Dergisi, 168-190. 